\title{
In vitro ESTABLISHMENT AND MULTIPLICATION OF GENOTYPES OF Eucalyptus dunnii MAIDEN
}

Marcio Carlos Navroski ${ }^{1 *}$, Lia Rejane Silveira Reiniger ${ }^{1}$, Maristela Machado Araújo ${ }^{1}$, Aline Ritter Curti ${ }^{1}$, Mariane de Oliveira Pereira $^{1}$

*Autor para correspondência: navroskiflorestal@yahoo.com.br

\begin{abstract}
This study aimed at evaluating the effect of genotypes of Eucalyptus dunnii on in vitro establishment and also the influence of genotypes grown in different concentrations of 6-Benzylaminopurine (BAP) on in vitro multiplication. Explants were obtained from 10 parent plants selected in the field as a function of their superior phenotype characteristics. For in vitro establishment, 10 genotypes were evaluated, while in vitro multiplication consisted of 30 treatments which corresponded to combinations of six genotypes found to succeed in the in vitro establishment and five BAP concentrations $(0,0.25,0.50,0.75$, and $1.0 \mathrm{mg} L-1)$. Different behaviors were observed regarding the genotypes as to in vitro establishment rates, in which genotypes 3, 6 and 7 had establishment rates of over $70 \%$, against $40 \%$ to $6.6 \%$ for the other genotypes. Genotypes 1, 5, 8 and 9 were later discarded due to the reduced number of explants successfully established. Factors such as microbial contamination and phenol oxidation posed a threat to in vitro establishment. The genotypes of Eucalyptus dunnii interacted differently with BAP in in vitro multiplication, noting that the concentration $0.50 \mathrm{mg} \mathrm{L-1}$ positively influenced bud formation on the explants in most genotypes. Hyperhydricity was relatively low when $0.50 \mathrm{mg} \mathrm{L-1} \mathrm{BAP} \mathrm{was} \mathrm{used} \mathrm{and} \mathrm{thus} \mathrm{does} \mathrm{not} \mathrm{pose} \mathrm{a} \mathrm{threat} \mathrm{to} \mathrm{in} \mathrm{vitro} \mathrm{multiplication} \mathrm{of} \mathrm{nodal} \mathrm{segments} \mathrm{of} \mathrm{Eucalyptus} \mathrm{dunnii.}$
\end{abstract}

Keywords: Vegetative propagation, tissue culture, micropropagation.

\section{ESTABELECIMENTO E MULTIPLICAÇÃO in vitro DE GENÓTIPOS DE Eucalyptus dunnii MAIDEN}

RESUMO: Conduziu-se este trabalho, com o objetivo de avaliar o efeito de genótipos de Eucalyptus dunnii no estabelecimento in vitro e a influência de genótipos cultivados em diferentes concentrações de 6-Benzilaminopurina (BAP) na multiplicação in vitro. Os explantes foram oriundos de 10 matrizes, selecionadas a campo em função de características fenotípicas superiores. Para o estabelecimento in vitro foram avaliados 10 genótipos, e, para a multiplicação in vitro, 30 tratamentos, que corresponderam às combinações de seis genótipos que obtiveram sucesso no estabelecimento in vitro com cinco concentrações de BAP $\left(0 ; 0,25 ; 0,50 ; 0,75 ;\right.$ e $\left.1,0 \mathrm{mg} \mathrm{L}^{-1}\right)$. Constatou-se comportamento diferenciado dos genótipos em relação ao estabelecimento in vitro, sendo que os genótipos 3, 6 e 7 apresentaram estabelecimento superior a $70 \%$, enquanto para os demais as médias variaram entre 40 e 6,6\%. Os genótipos 1, 5, 8 e 9 foram, posteriormente, descartados em virtude do número reduzido de explantes estabelecidos. A contaminação microbiana e a oxidação fenólica constituíram fatores que comprometem o estabelecimento in vitro. Os genótipos de Eucalyptus dunnii interagem de maneira diferenciada com BAP na multiplicação in vitro, porém a concentração $0,50 \mathrm{mg} \mathrm{L}^{-1}$ influencia positivamente a formação de gemas por explante na maior parte dos genótipos estudados. A hiperhidricidade é relativamente baixa na presença de $0,50 \mathrm{mg} \mathrm{L}^{-1}$ de BAP, não comprometendo a multiplicação in vitro de segmentos nodais de Eucalyptus dunnii.

Palavras-chave: Propagação vegetativa, cultura de tecidos, micropropagação.

\section{INTRODUCTION}

Clonal forestry with Eucalyptus species is a well established and advanced practice that has been adopted by most Brazilian forest-based companies. Among other advantages, it enables standardization of tree stands, maximization of gains both in productivity and in wood quality, better adaptation of clones to the relevant plantation area, in addition to allowing use of specific hybrid combinations, along with rationalization of the operational activities and the benefits of competitive costs (ALFENAS et al., 2009; ASSIS et al., 2004).

Among existing species, Eucalyptus dunnii has been one of particular significance in southern Brazil,

${ }^{1}$ Universidade Federal de Santa Maria - Santa Maria, Rio Grande do Sul, Brasil

Cerne, Lavras, v. 20, n. 1, p. 139-146, jan./mar. 2014 
not only because it is fast growing and because of its outstanding shape but mainly because it is tolerant of frost. Additionally, this particular species has a low invasive potential as it produces few seeds, and that in turn prevents random propagation (BILLARD; LALLANA, 2005). Yet, as another point of view, seed scarcity poses a serious obstacle to seedling production via the sexual method. And so, alternatively, asexual propagation methods should be investigated, including micropropagation, a technique that in recent years has aroused particular interest. Micropropagation has emerged as a promising technique to enable mass cloning of Eucalyptus dunnii hybrids, as these have rooting difficulties if otherwise propagated by the cutting method, especially where adult material is concerned (ALFENAS et al., 2009; ASSIS et al., 2004).

In micropropagation, protocol success will clearly depend on the in vitro establishment stage, the reason being that the succeeding multiplication stage and subsequent transfer to ex vitro conditions can only be attained if aseptic cultures with good vegetative vigor have been obtained in the establishment stage. A number of factors influence success of micropropagation, including genotype, physiological state of the parent plant, selection, collection and type of explant used, asepsis method, culture medium, and also concentrations and types of growth regulators (GEORGE; DEBERGH, 2008; XAVIER et al., 2007).

Given the importance of Eucalyptus dunnii today for the forestry sector, particularly for the pulp and paper industry, and the lack of studies investigating its clonal propagation, a study is thus justified to explore responses to in vitro establishment and multiplication of phenotypically superior genotypes.

With that in mind, this study aimed to evaluate the effect of genotypes of Eucalyptus dunnii on in vitro establishment and also the influence of genotypes grown in different concentrations of cytokinin 6-Benzylaminopurine (BAP) on in vitro multiplication.

\section{MATERIAL AND METHODS}

\subsection{Collection and preparation of genetic material}

The genetic material used in this study was obtained from areas owned by StoraEnso, a company located in the municipality of Rosário do Sul - RS, more specifically from three-year-old commercial stands of Eucalyptus dunnii that were originated by the seed planting method.

Cerne, Lavras, v. 20, n. 1, p. 139-146, jan./mar. 2014
Ten trees were selected for their superior height and diameter, robust crown development and absence of nutrient and water deficiency symptoms or disease and pest attacks. These trees were felled, leaving behind a stump about $45 \mathrm{~cm}$ in height. After shoots started to emerge, some preventive sanitary treatments were performed which included alternate weekly application of the fungicides Captan ${ }^{\circledR}$ (dicarboximide) at $2.4 \mathrm{~g} \mathrm{~L}^{-1}$, and Benomyl ${ }^{\circledR}$ (benzimidazole) at $1.0 \mathrm{~g} \mathrm{~L}^{-1}$.

Sixty days after tree felling, shoots were collected, separating the 3rd and 4th pairs of leaves from tip to base, which is the position commonly used to form Eucalyptus minicuttings. The shoots were collected early in the morning, and the cuttings were stored in glass containers containing sterile water plus ascorbic acid at $1 \%(\mathrm{w} / \mathrm{v})$ to minimize the effect of phenol oxidation. The containers with the cuttings were then placed in a polystyrene box containing ice and transferred to a laboratory. The transfer time to the laboratory was around 3 hours.

\subsection{In vitro establishment of nodal segments}

Once in the laboratory, the minicuttings were rinsed in running water for about 30 minutes in order to leach phenolic substances and reduce surface contaminants. Following initial cleansing, the minicuttings were submerged in neutral detergent $\left(1 \mathrm{~mL} \mathrm{~L}^{-1}\right)$ for 1-2 minutes and rinsed three times using sterile water. Following this stage, nodal segments $1.0-1.5 \mathrm{~cm}$ in length and containing one pair of axillary buds were cut and thoroughly rinsed with sterile water.

A laminar flow cabinet was used for decontamination, with the nodal segments being immersed in a $70 \%$ ethanol solution $(\mathrm{v} / \mathrm{v})$ for 30 seconds, rinsed with sterile water and then immersed in a sodium hypochlorite solution - $\mathrm{NaOCl}$ $(1.5 \% \mathrm{v} / \mathrm{v})$ for 10 minutes. Next, the nodal segments were rinsed three times with sterile water and immediately inoculated upright into jar containers with a capacity of $150 \mathrm{~mL}$ containing $30 \mathrm{~mL}$ of MS medium (MURASHIGE; SKOOG, 1962).

Into the MS medium were added $6 \mathrm{~g} \mathrm{~L}^{-1}$ agar and 30 $\mathrm{g} \mathrm{L}^{-1}$ sucrose, and $\mathrm{pH}$ was adjusted to 5.8 . The containers containing the nutrient medium were then autoclaved at $121^{\circ} \mathrm{C}(1.5 \mathrm{kgf} \mathrm{cm}-2)$ for 20 minutes. The nutrient medium was supplemented with $0.1 \mathrm{mg} \mathrm{L}^{-1} \mathrm{BAP}$ and $0.01 \mathrm{mg} \mathrm{L}^{-1}$ alpha-naphthalene acetic acid (alpha-NAA), following recommendations by Alfenas et al. (2009). Also added were $100 \mathrm{mg} \mathrm{L}^{-1}$ myo-inositol and $250 \mathrm{mg} \mathrm{L}^{-1}$ 
polyvinylpyrrolidone (PVP), in order to control phenol oxidation.

Following inoculation of the explants into the nutrient medium, the jar containers were kept in a growth room at a temperature of $25^{\circ} \mathrm{C} \pm 2^{\circ} \mathrm{C}$, for a photoperiod of 16 hrs. under light intensity of $20 \mu \mathrm{mol} \mathrm{m}^{-2} \mathrm{~s}^{-1}$ as provided by cool white daylight fluorescent lamps throughout the trial.

Thirty days after inoculation, an analysis was done to determine the percentage of explants successfully established in vitro (shoots), along with phenol oxidation and overall contamination (fungi + bacteria). Established explants are defined as those segments that resumed growth after inoculation so as to form new buds or leaves. Phenol oxidation and overall contamination were determined by visually assessing the explants for presence of darkened spots and for presence of fungi and bacteria in the nutrient medium and/or explants.

For the in vitro establishment of genotypes, a completely randomized design was used, each of the 10 genotypes being considered one treatment. Five replicates were used, each consisting of three explants per jar container, to a total of 50 trial units and 150 nodal segments introduced in vitro.

\subsection{In vitro multiplication of explants}

To begin the multiplication stage, nodal segments containing two axillary buds from the previously described in vitro establishment stage were cut and inoculated, under aseptic conditions, into jar containers with a capacity of $150 \mathrm{~mL}$ that in turn contained $30 \mathrm{~mL}$ of MS medium and had the concentration of mineral salts reduced by half $(1 / 2$ MS), supplemented with different BAP concentrations according to treatment, and $0.01 \mathrm{mg} \mathrm{L}^{-1} \mathrm{NAA}$.

Into the MS medium were also added $6 \mathrm{~g} \mathrm{~L}^{-1}$ agar, $30 \mathrm{~g} \mathrm{~L}^{-1}$ sucrose and $50 \mathrm{mg} \mathrm{L}^{-1}$ myo-inositol. The medium was prepared using deionized water and the $\mathrm{pH}$ was adjusted to 5.8, prior to autoclaving and adding the agar. The containers were then sealed with aluminum foil and autoclaved at $\left.121^{\circ} \mathrm{C}(1.5 \mathrm{kgf} \mathrm{cm})^{-2}\right)$ for 20 minutes. The growth conditions were identical to those described for the in vitro establishment stage.

The experiment was laid out in a completely randomized design using a $6 \times 5$ factorial whereby levels of the 'A' factor referred to genotypes and levels of the ' $\mathrm{B}$ ' factor referred to BAP concentrations $(0,0.25,0.50,0.75$, and $\left.1.0 \mathrm{mg} \mathrm{L}^{-1}\right)$. Five replicates were used, each consisting of three explants per container to a total of 150 trial units and 450 nodal segments introduced in vitro.

Thirty days after inoculation, the explants were checked to determine the number of axillary buds formed per explant unit along with the percentage of hyperhydric explants. Hyperhydricity was determined by visual assessment and any explant with a vitrified aspect was defined as hyperhydric.

\subsection{Statistical analysis}

Data were subjected to the Kolmogorov-Smirnov test for error normality and to the Bartlett's test for variance homogeneity, and then processed by the function $\sqrt{x+0,5}$ and subjected, if required, to analysis of variance (PONTES, 2005). When the F value was significant, means of qualitative treatments were subjected to the Scott-Knott test at the $5 \%$ error probability level. Means of quantitative treatments, in turn, were subjected to polynomial regression analysis. The provided results are the original means obtained. SISVAR software (FERREIRA, 2000) was used for the statistical analysis of data. Trial accuracy was measured by the selective accuracy statistic (AS), calculated as $\sqrt{1-1 / F c a l}$ and corresponding to the linear correlation between genotypic and phenotypic values.

\section{RESULTS AND DISCUSSION}

\subsection{In vitro establishment}

The different genotypes showed significant differences for in vitro establishment $(\mathrm{P}<0.0001)$, for phenol oxidation $(\mathrm{P}=0.0074)$ and for overall contamination $(\mathrm{P}=0.0451)$. The selective accuracy statistic $(\mathrm{AS})$ was high for establishment rate $(0.87)$ and phenol oxidation $(0.70)$ but moderate for overall contamination (0.46), according to a classification developed by Resende and Duarte (2007), denoting that the variables of interest had differentiated values for purposes of selecting best genotypes of Eucalyptus dunnii in in vitro establishment. For the first two variables, results of selective accuracy revealed a high correlation between genotypic and phenotypic characteristics, denoting that a high level of confidence can be placed in the assessment, unlike what was observed for overall contamination.

Regarding - establishment, genotypes 3, 6 and 7 had establishment rates of over $70 \%$ (Table 1), which is considered a satisfactory result given that the sampled material was obtained in the field and contamination rates

Cerne, Lavras, v. 20, n. 1, p. 139-146, jan./mar. 2014 
by microorganisms in such environment are typically high and frequent (ALMEIDA et al., 2008). Additionally, one should take into account that the relatively high length of time spent in transferring the explants to the laboratory potentially contributes to phenol oxidation of the explants. The remaining genotypes had lower establishment rates, averaging between $40 \%$ and $6.6 \%$ and not differing statistically from each other. Among them, genotypes 1, 5,8 and 9 were later discarded due to the reduced number of explants successfully established.

The genotypes showing the highest in vitro establishment rates were those that concurrently had the lowest percentage of phenol oxidation and contamination (Table 1). This influence exerted by oxidation and contamination on the establishment rates of explants was demonstrated by computing Pearson's correlation between such variables (Table 2).

Tabela 1 - Médias de estabelecimento in vitro, oxidação fenólica e contaminação geral, expressas em porcentagem, de segmentos nodais de Eucalyptus dunnii cultivados em meio nutritivo MS, aos 30 dias de cultivo in vitro, provenientes de dez genótipos isolados de cepas de indivíduos de cerca de três anos de idade. Santa Maria-RS.

Table 1 - Means of in vitro establishment, phenol oxidation and overall contamination expressed as percentage for nodal segments of Eucalyptus dunnii grown in MS medium, after 30 days of in vitro culture, and obtained from ten isolate genotypes of three-year-old individuals. Santa Maria-RS.

\begin{tabular}{cccc}
\hline Genotype & $\begin{array}{c}\text { In vitro } \\
\text { establishment } \\
\text { rate (\%) }\end{array}$ & $\begin{array}{c}\text { Phenol } \\
\text { oxidation (\%) }\end{array}$ & $\begin{array}{c}\text { Overall } \\
\text { contamina- } \\
\text { tion* }(\%)\end{array}$ \\
\hline 7 & $80.0 \mathrm{a}$ & $19.98 \mathrm{a}$ & $6.67 \mathrm{a}$ \\
6 & $73.6 \mathrm{a}$ & $13.32 \mathrm{a}$ & $6.67 \mathrm{a}$ \\
3 & $73.4 \mathrm{a}$ & $26.64 \mathrm{a}$ & $13.32 \mathrm{a}$ \\
4 & $40.0 \mathrm{~b}$ & $46.62 \mathrm{~b}$ & $26.66 \mathrm{a}$ \\
2 & $33.2 \mathrm{~b}$ & $53.28 \mathrm{~b}$ & $26.66 \mathrm{a}$ \\
10 & $33.2 \mathrm{~b}$ & $55.66 \mathrm{~b}$ & $6.67 \mathrm{a}$ \\
1 & $13.2 \mathrm{~b}$ & $66.64 \mathrm{~b}$ & $53.32 \mathrm{~b}$ \\
9 & $13.2 \mathrm{~b}$ & $73.28 \mathrm{~b}$ & $39.98 \mathrm{~b}$ \\
5 & $13.2 \mathrm{~b}$ & $66.64 \mathrm{~b}$ & $60.00 \mathrm{~b}$ \\
8 & $6.6 \mathrm{~b}$ & $66.64 \mathrm{~b}$ & $59.96 \mathrm{~b}$ \\
\hline Mean & 38.0 & 48.87 & 29.99 \\
AS2 & 0.87 & 0.70 & 0.46 \\
\hline
\end{tabular}

* Bacterial or fungal contamination or both. ${ }^{1}$ Means followed by the same letter in a column do not differ by the Scott-Knott test at the $5 \%$ error probability level. ${ }^{2} \mathrm{AS}=$ selective accuracy range ( $\leq 0.5$ : low; $0.5<\mathrm{AS} \geq 0.7$ : moderate; $0.7<\mathrm{AS} \geq 0.9$ : high; $>0.9$ : very high)

Cerne, Lavras, v. 20, n. 1, p. 139-146, jan./mar. 2014
Tabela 2 - Coeficientes de correlação de Pearson entre as variáveis avaliadas no estabelecimento in vitro de dez genótipos. Santa Maria-RS.

Table 2 - Coefficients of Pearson correlation between variables evaluated in vitro establishment ten genotypes. Santa Maria-RS.

\begin{tabular}{llll}
\hline Variable & $\begin{array}{l}\text { In vitro } \\
\text { establish- } \\
\text { ment (\%) }\end{array}$ & $\begin{array}{l}\text { Phenol } \\
\text { oxidation } \\
(\%)\end{array}$ & $\begin{array}{l}\text { Overall } \\
\text { contamina- } \\
\text { tion }(\%)\end{array}$ \\
\hline In vitro establishment (\%) & 1 & $-0.9732^{* *}$ & $-0.8356^{* *}$ \\
Phenol oxidation (\%) & - & 1 & $0.7632^{*}$ \\
Overall contamination (\%) & - & - & 1 \\
\hline
\end{tabular}

${ }^{*}$ and ${ }^{* *}$ : significant correlation coefficients at the $5 \%$ and $1 \%$ levels respectively.

These associations partially explain the results and are consistent with the findings of Alfenas et al. (2009) and Xavier et al. (2009), who reported that, other thanthe genotypic effect, phenol oxidation and microbial contamination are responsible for higher or lower in vitro establishment rates of explants, noting that reduced levels of contamination and oxidation do not affect tissue cultures so much as to render them unfeasible (XAVIER et al., 2009).

Despite the negative effects of phenol oxidation and overall contamination, results obtained throughout the micropropagation process, not least in the establishment stage, are directly influenced by genotype, this being one of the most limiting factors in the success of in vitro propagation. That owes to the peculiarities of species and individuals, as to nutrient medium and environment conditions, which are controlled by genetic factors. Therefore, when working with new genotypes, it is recommended to assess the response of such materials to in vitro growth and then make the necessary adjustments to optimize the micropropagation process (GAHAN; GEORGE, 2008).

In the in vitro establishment stage, relatively wide variation was found in the average percentage of explants established and oxidized in different genotypes (Table 1). It is possible that this amplitude of response is due to existing differences among the genotypes, given that the parent plants from which the explants were obtained originated from the seed planting method.

\subsection{In vitro multiplication}

In in vitro multiplication, the number of axillary buds per explant revealed a significant interaction between the genotypes and BAP concentrations $(\mathrm{P}=0.0024)$, which means the genotypes differed in behavior with changing BAP concentrations in the nutrient medium. 
Hyperhydricity was significantly influenced $(\mathrm{P}<0.0001)$ only by BAP concentrations.

The selective accuracy statistic was considerably high for the variable number of buds (0.91) and moderate (0.62) for hyperhydricity. Since the higher the accuracy, the greater the confidence that can be placed in the assessment and in predicted values, the variables of interest had differentiated values for purposes of selecting best genotypes of Eucalyptus dunnii in in vitro multiplication.
Thirty days after inoculating the explants into jar containers, a significant quadratic polynomial was obtained for multiplication of buds in all six genotypes (Figure 1). Genotype 7 had the highest number of buds, averaging 5.33 buds with the concentration $0.25 \mathrm{mg} \mathrm{L}^{-1}$ BAP. However, maximum technical effectiveness would be achieved with around $0.51 \mathrm{mg} \mathrm{L}^{-1}$ of the above cytokinin.

A similar behavior to that of genotype 7 was found for genotype 6 in that the largest number of buds (4.33)
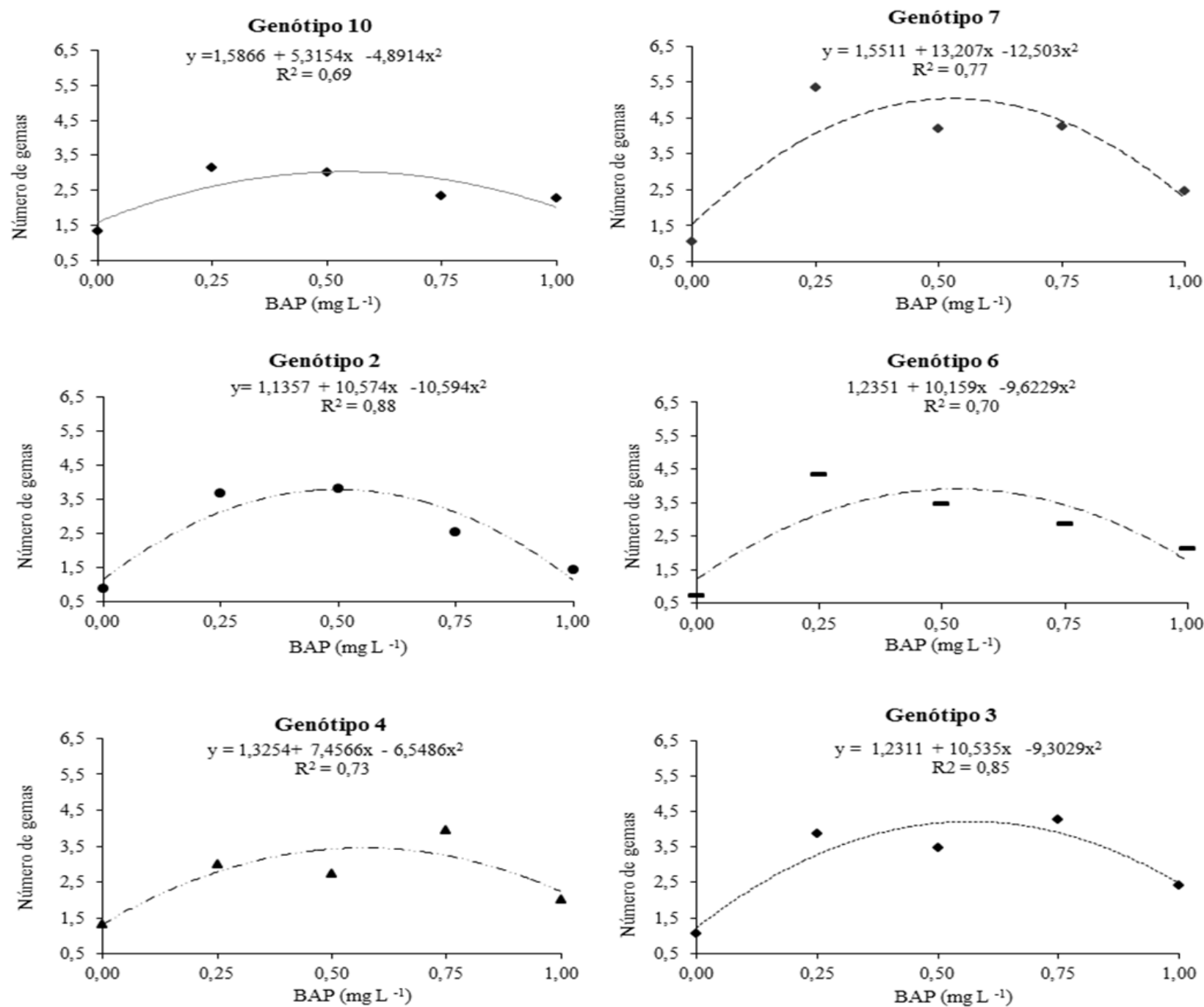

Figura 1 - Número de gemas por explante em seis genótipos de Eucalyptus dunnii, após 30 dias de cultivo in vitro em meio nutritivo MS com concentração de sais reduzida à metade (1/2 MS) e acrescido de diferentes concentrações de 6-Benzilaminopurina (BAP). Santa Maria - RS.

Figure 1 - Number of buds by explant in six genotypes of Eucalyptus dunnii, after 30 days of in vitro culture in nutritive medium MS with half of salt concentration $(1 / 2 M S)$ and added of different concentrations of 6-Benzylaminopurine (BAP). Santa Maria - RS.

Cerne, Lavras, v. 20, n. 1, p. 139-146, jan./mar. 2014 
was obtained by using the same BAP concentration $(0.25$ $\mathrm{mg} \mathrm{L}^{-1}$ ), noting that the number of buds decreased with increasing concentrations of the above cytokinin. Genotype 10 had a similar behavior in that it averaged the highest number of buds with $0.25 \mathrm{mg} \mathrm{L}^{-1}$ BAP. However, unlike the other genotypes, it averaged the lowest number of buds formed per explant (3.13). For genotypes 6 and 10, maximum technical effectiveness would be attained with $0.50 \mathrm{mg} \mathrm{L}^{-1}$ of the cytokinin.

Similarly to genotype 10 , genotype 2 had inferior performance despite averaging its highest number of buds (3.80) in the presence of $0.50 \mathrm{mg} \mathrm{L}^{-1} \mathrm{BAP}$, a number that gradually decreased to 1.40 buds per explant with use of $1.00 \mathrm{mg} \mathrm{L}^{-1}$ of the cytokinin. For this genotype, maximum technical effectiveness would be attained with $0.50 \mathrm{mg} \mathrm{L}^{-1} \mathrm{BAP}$.

Genotypes 3 and 4 had identical performance, forming their largest number of buds when $0.75 \mathrm{mg} \mathrm{L}^{-1}$ BAP was added to the medium, with average numbers ( 4.27 and 4.67 respectively) gradually decreasing with increasing concentrations. For genotypes 3 and 4, maximum technical effectiveness would be attained with addition of $0.57 \mathrm{mg} \mathrm{L}^{-1}$ BAP to the $1 / 2 \mathrm{MS}$ medium.

Considering all six genotypes tested, the 0.25 to $0.75 \mathrm{mg} \mathrm{L}^{-1}$ range of BAP concentration provided the largest numbers of axillary buds. Yet, considering estimations of maximum technical effectiveness, the best
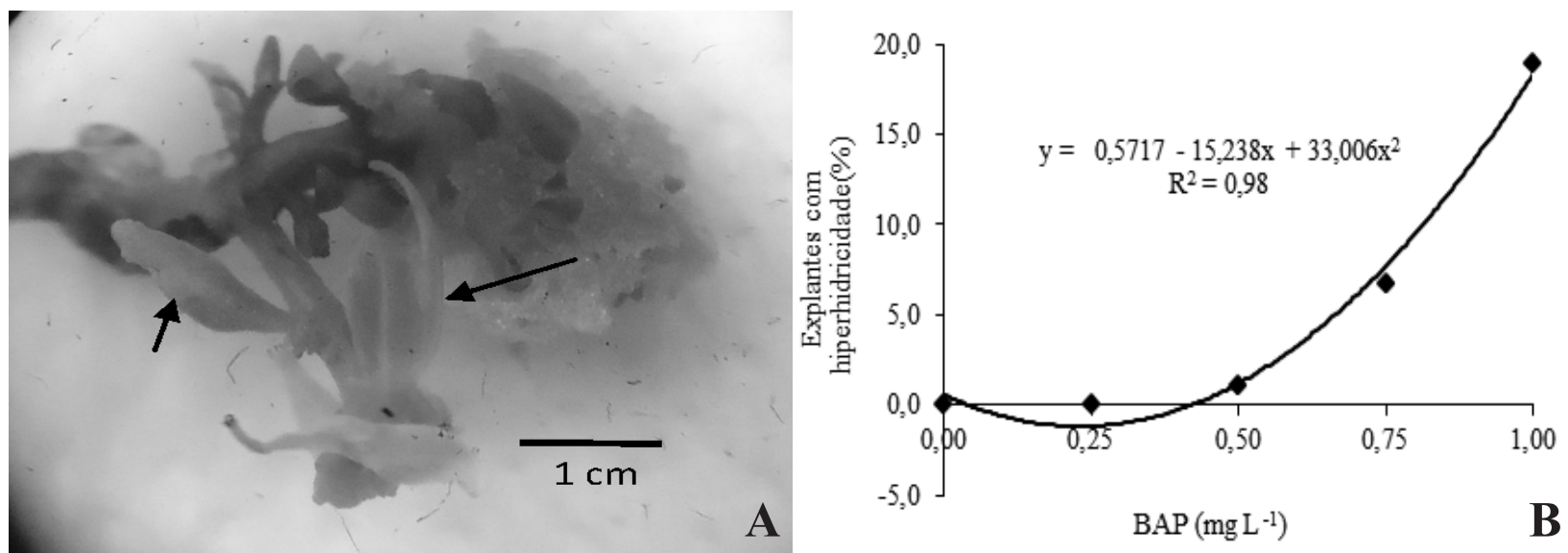

Figura 2 - A - Aspecto de brotações de Eucalyptus dunnii com hiperhidricidade (indicações nas setas). B - hiperhidricidade (\%) após 30 dias de cultivo in vitro em meio nutritivo MS reduzido à metade da concentração de sais ( $1 \frac{1}{2}$ MS) acrescido de diferentes concentrações de 6-Benzilaminopurina (BAP). Santa Maria-RS.

Figure 2 - A - Appearance of shoots of Eucalyptus dunnii with hyperhydricity (indications arrows). B - hyperhydricity (\%) after 30 days of in vitro culture in the medium MS with half of the salt concentration ( $1 / 2 \mathrm{MS})$ supplemented with different concentrations of 6-benzylaminopurine (BAP). Santa Maria-RS.

Cerne, Lavras, v. 20, n. 1, p. 139-146, jan./mar. 2014 
benthamii hybrids using $1.0 \mathrm{mg} \mathrm{L}^{-1} \mathrm{BAP}$ in the in vitro multiplication stage (BRONDANI et al., 2009).

\section{CONCLUSIONS}

The genotypes of Eucalyptus dunnii differed in performance with respect to in vitro establishment rate, microbial contamination and phenol oxidation of nodal segments grown in MS medium, after 30 days of in vitro culture.

The genotypes of Eucalyptus dunnii interacted differently with the cytokinin BAP in in vitro multiplication, noting that, overall, the concentration $0.50 \mathrm{mg} \mathrm{L}^{-1}$ positively influenced most genotypes as to the buds formed per explant and as to the low hyperhydricity observed, therefore not affecting in vitro multiplication of nodal segments.

\section{REFERÊNCIAS}

ALFENAS, A. C.; ZAUZA, E. A. V.; MAFIA, R. G.; ASSIS, T. F. de. Clonagem e doenças do eucalipto. 2. ed. Viçosa, MG: UFV, 2009. 500 p.

ALMEIDA, J. R.; MARTINS, C. R.; DUTRA, L. F. Desinfestação de segmentos nodais de Eucalyptus dunnii visando estabelecimento in vitro. Revista da FZVA, Uruguaiana, v. 15, n. 1, p. 54-60, 2008.

ASSIS, T. F.; FETT-NETO, A. G.; ALFENAS, A. C. Current techniques and prospects for the clonal propagation of hardwoods with emphasis on Eucalyptus. In: WALTER, C.; CARSON, M. (Ed.). Plantation forest biotechnology for the 21th century. Kerala: Research Signpost, 2004. p. 303-333.

BILLARD, C. E.; LALLANA, V. H. Multiplicación in vitro de Eucalyptus dunnii. Ciência, Docência y Tecnologia, Concepción del Uruguay, ano 16, n. 30, p. 199-216, 2005.

BRONDANI, G. E.; DUTRA, L. F.; GROSSI, F.; WENDLING, I.; HORNIG, J. Estabelecimento, multiplicação e alongamento in vitro de Eucalyptus benthamii Maiden \& Cambage $\mathrm{x}$ Eucalyptus dunnii Maiden. Revista Árvore, Viçosa, v. 33, n. 1, p. 11-19, 2009.

FERREIRA, D. F. Sistemas de análise estatística para dados balanceados. Lavras: UFLA, 2000. 145 p.
GAHAN, P. B.; GEORGE, E. F. Adventitious regeneration. In: GEORGE, E. F.; HALL, M. A.; DE KLERK, G. J. (Ed.). Plant propagation by tissue culture. Dordrech: Springer, 2008. v. 1, p. 355-402.

GEORGE, E. F.; DEBERGH, P. C. Micropropagation: uses and methods. In: GEORGE, E. F.; HALL, A. M.; DE KLERK, G. J. (Ed.). Plant propagation by tissue culture: the background. 3rd ed. Dordrecht: Springer, 2008. v. 1, p. 29-64.

GRATTAPAGLIA, D.; MACHADO, M. A.

Micropropagação. In: TORRES, A. C.; CALDAS, L. S.; BUSO, J. A. (Ed.). Cultura de tecidos e transformação genética de plantas. Brasília: EMBRAPA-SPI/ EMBRAPA-CNPH, 1998. p. 183-260.

MURASHIGE, T.; SKOOG, F. A revised medium for rapid growth and bioassays with tobacco tissue cultures. Physiologia Plantarum, Copenhagen, v. 15, p. 473-497, 1962.

PAEK, K. Y.; HAN, B. H.; CHOI, J. K. Physiological biochemical and morphological characteristics of vitrification shoot regenerated in vitro. Korean Journal of Plant Tissue Culture, Bangladesh, v. 18, n. 3, p. 151$162,1991$.

PONTES, A. C. F. Análise de variância multivariada com utilização de testes não paramétricos e componentes principais baseados em matrizes de postos. 2005. 106 p. Tese (Doutorado em Agronomia) - Escola Superior de Agricultura "Luiz de Queiroz", Piracicaba, 2005.

RESENDE, M. D. V.; DUARTE, J. B. Precisão e controle de qualidade em experimentos de avaliação de cultivares. Pesquisa Agropecuária Tropical, Goiânia, v. 37, n. 3, p. 182-194, 2007.

XAVIER, A.; OTONI, W. C.; PENCHEL, R. M. Micropropagação e enxertia in vitro de espécies florestais. In: BORÉM, A. (Ed.). Biotecnologia florestal. Viçosa, MG: Suprema, 2007. p. 55-74.

Received: March 29, 2012; aceepted: August 21, 2013.

Cerne, Lavras, v. 20, n. 1, p. 139-146, jan./mar. 2014 
